\title{
Perivascular and Subarachnoid Fluid-Attenuated Inversion Recovery Hyperintensities Related to Delayed Gadolinium Leakage After Stroke
}

Larisa Nistorec, MD, Dimitri Renard, MD, and Teodora Parvu, MD

Neurology ${ }^{\circledR}$ 2021;97:1000-1001. doi:10.1212/WNL.0000000000012854

Figure Imaging Results

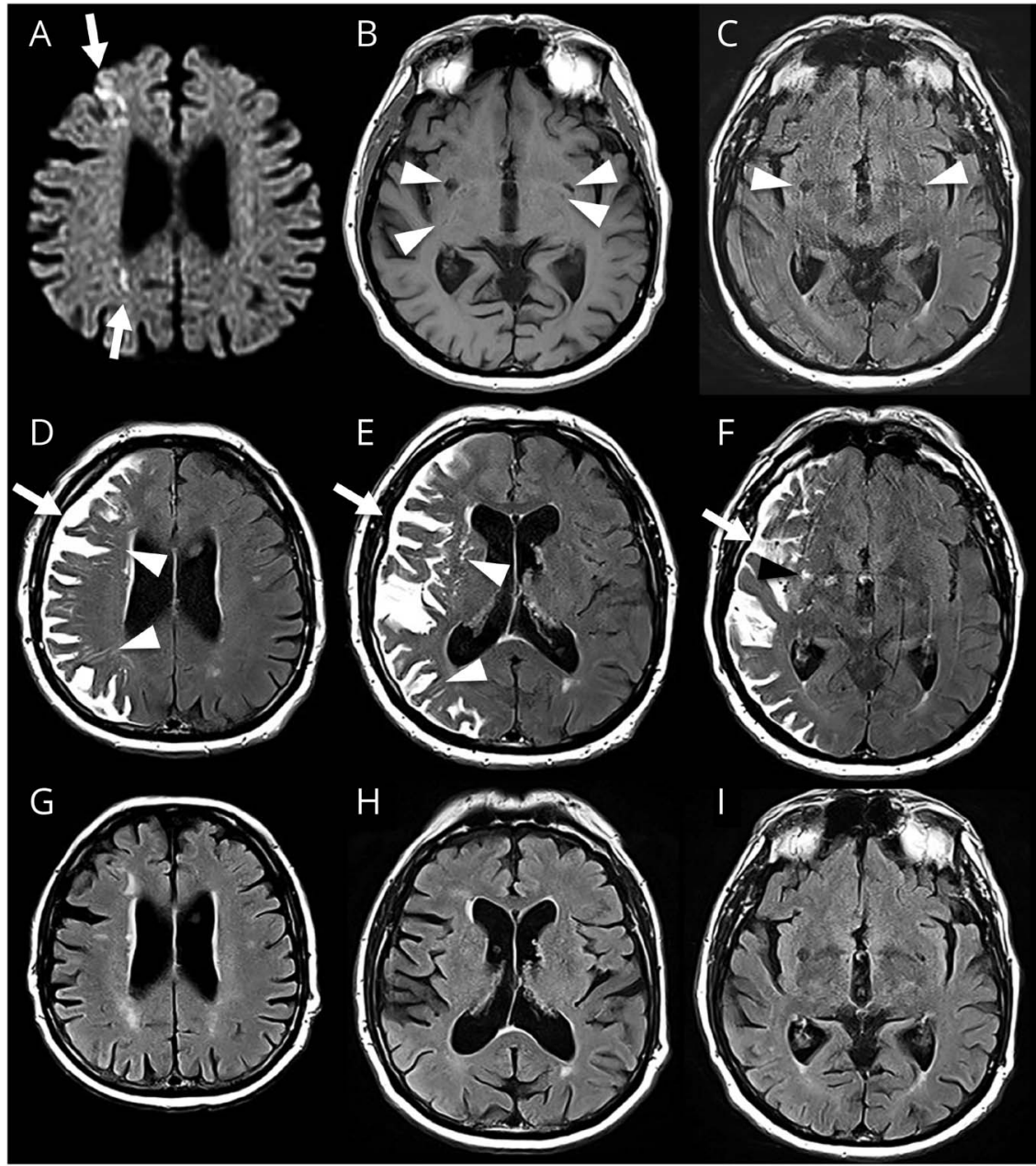

Initial MRI (gadolinium-injected for magnetic resonance angiography) shows right-sided infarction (A, diffusionweighted imaging) and perivascular spaces (PVS) (B, T1-weighted imaging; $C$, fluid-attenuated inversion recovery [FLAIR]). (D-F) Four hours later, MRI shows ipsilateral subarachnoid (arrows) and deep and subcortical PVS (arrowheads) gadolinium leakage seen as FLAIR hyperintensities. (G-I) Complete resolution of subarachnoid/perivascular FLAIR abnormalities was observed 10 days later.

A 74-year-old man presented with right watershed infarction (initial gadolinium-injected MRI, Figure). Renal function was normal. MRI 4 hours later showed ipsilateral perivascular spaces (PVS) and subarachnoid fluid-attenuated inversion recovery (FLAIR) hyperintensities,
Correspondence

Dr. Parvu

teodora.parvu@chu-nimes.fr 
probably related to stroke-associated delayed gadolinium leakage (Figure). MRI after 10 days showed complete resolution of subarachnoid/perivascular abnormalities (Figure).

Stroke-related subarachnoid and ocular gadolinium leakage on FLAIR probably represents blood-brain/ocular barrier disruption. ${ }^{1,2, \mathrm{e} 1}$ An earlier report described PVS gadolinium leakage on MRI performed $>1$ month after stroke. ${ }^{\text {el }}$ The glymphatic system (playing a role in CSF-interstitial fluid interchange) may be involved in stroke-related blood-brain barrier leakage observed in the subarachnoid space and PVS.

\section{Study Funding}

The authors report no targeted funding.

\section{Disclosure}

The authors do not have any financial or other contributions to disclose. Go to Neurology.org/N for full disclosures.

\section{Appendix Authors}

\begin{tabular}{lll}
\hline Name & Location & Contribution \\
\hline $\begin{array}{l}\text { Larisa } \\
\text { Nistorec, } \\
\text { MD }\end{array}$ & $\begin{array}{l}\text { Department of Neurology, } \\
\text { Fimes University Hospital, }\end{array}$ & $\begin{array}{l}\text { Drafting/revision of the } \\
\text { manuscript for content, including } \\
\text { medical writing for content }\end{array}$ \\
\hline $\begin{array}{l}\text { Dimitri } \\
\text { Renard, } \\
\text { MD }\end{array}$ & $\begin{array}{l}\text { Department of Neurology, University Hospital, } \\
\text { France }\end{array}$ & $\begin{array}{l}\text { Drafting/revision of the } \\
\text { manuscript for content, including } \\
\text { medical writing for content }\end{array}$ \\
\hline $\begin{array}{l}\text { Teodora } \\
\text { Parvu, } \\
\text { MD }\end{array}$ & $\begin{array}{l}\text { Department of Neurology, } \\
\text { Nimes University Hospital, }\end{array}$ & $\begin{array}{l}\text { Drance } \\
\text { manuscript for content, including } \\
\text { medical writing for content }\end{array}$ \\
\hline
\end{tabular}

\section{References}

1. Latour LL, Kang DW, Ezzeddine MA, Chalela JA, Warach S. Early blood-brain barrier disruption in human focal brain ischemia. Ann Neurol. 2004;56(4):468-477.

2. Warach S, Latour LL. Evidence of reperfusion injury, exacerbated by thrombolytic therapy, in human focal brain ischemia using a novel imaging marker of early bloodbrain barrier disruption. Stroke. 2004;35(11 suppl 1):2659-2661.

Supplemental data (eReference 1) is available at: links.lww.com/WNL/B552

\section{Quality Improvement for Neurology}

Not sure where or how to start driving quality improvement in practice? Visit AAN.com/practice/quality to find resources and tools to help you start.

\section{Manage Your Career | Recruit Top Talent}

The AAN's Neurology Career Center is the largest job site specifically for neurologists. Visit careers.aan.com to find your next hire or search from hundreds of open positions in neurology.

\section{Announcing... Child Neurology: A Case-Based Approach Cases From the Neurology ${ }^{\circ}$ Resident \& Fellow Section}

This collaboration between the American Academy of Neurology (AAN) and the Child Neurology Society (CNS) represents a collection of reprinted cases from the past 15 years from the Neurology Resident \& Fellow Section.

An invaluable resource for both adult and pediatric neurologists and trainees! FREE download: NPub.org/cnbook 


\title{
Neurology
}

\section{Perivascular and Subarachnoid Fluid-Attenuated Inversion Recovery Hyperintensities Related to Delayed Gadolinium Leakage After Stroke}

\author{
Larisa Nistorec, Dimitri Renard and Teodora Parvu
}

Neurology 2021;97;1000-1001 Published Online before print September 23, 2021

DOI 10.1212/WNL.0000000000012854

This information is current as of September 23, 2021

Updated Information \&

Services

References

Subspecialty Collections

Permissions \& Licensing

Reprints including high resolution figures, can be found at: http://n.neurology.org/content/97/21/1000.full

This article cites 2 articles, 1 of which you can access for free at: http://n.neurology.org/content/97/21/1000.full\#ref-list-1

This article, along with others on similar topics, appears in the following collection(s):

\section{Infarction}

http://n.neurology.org/cgi/collection/infarction

Information about reproducing this article in parts (figures,tables) or in its entirety can be found online at:

http://www.neurology.org/about/about_the_journal\#permissions

Information about ordering reprints can be found online:

http://n.neurology.org/subscribers/advertise

Neurology ${ }^{\circledR}$ is the official journal of the American Academy of Neurology. Published continuously since 1951, it is now a weekly with 48 issues per year. Copyright (C 2021 American Academy of Neurology. All rights reserved. Print ISSN: 0028-3878. Online ISSN: 1526-632X.

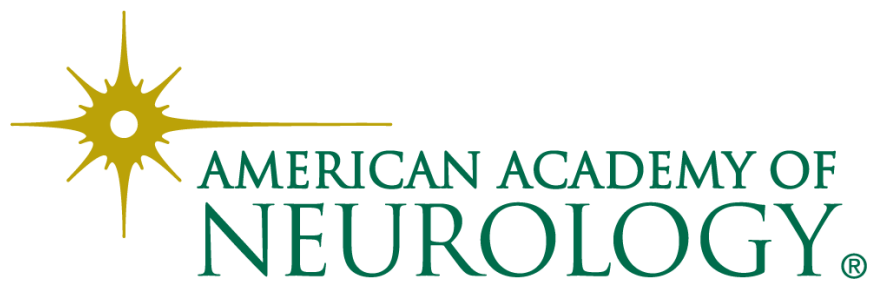

